
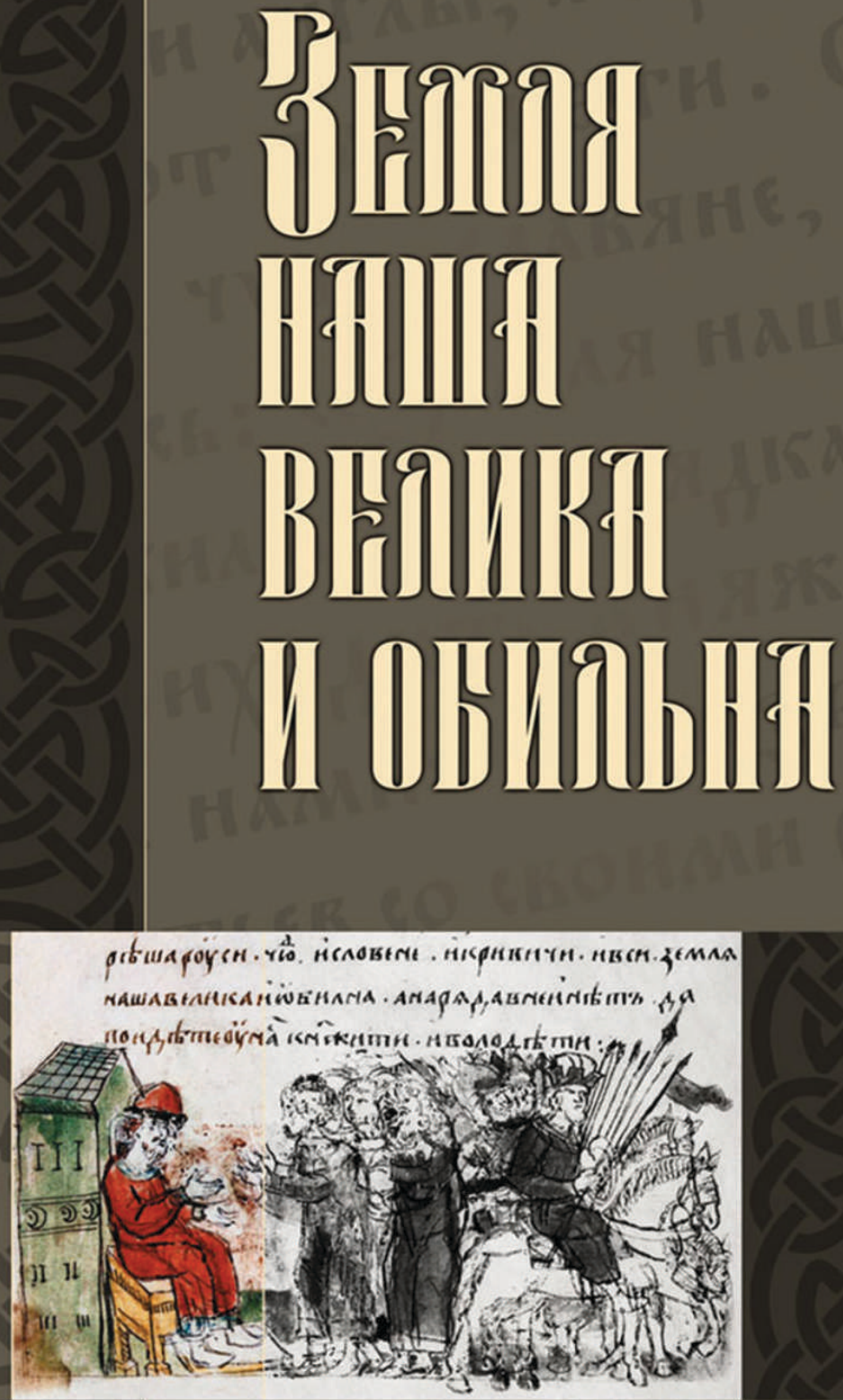


\author{
РОССИЙСКАЯ АКАДЕМИЯ НАУК \\ ИНСТИТУТ ИСТОРИИ МАТЕРИАЛЬНОЙ КУЛЬТУРЫ \\ АНО «ИНСТИТУТ АРХЕОЛОГИИ СЕВЕРА» \\ ООО «НПО «СЕВЕРНАЯ АРХЕОЛОГИЯ-1»
}

\title{
ЗЕМЛЯ НАША
}

\section{ВЕЛИКА И ОБИЛЬНА...}

90-летию А. Н. Кирпичникова посвящается 
УДК 902

ББК 63.4(2)

Благодарим за финансовую поддержку данного издания

Георгия Петровича Визгалова и Олега Викторовича Кардаша

Ответственный редактор:

С. В. Белецкий

Редколлегия:

Г. П. Визгалов, Т. Н. Джаксон, М. М. Казанский, О. В. Кардаш, В. А. Лапшин, А. И. Сакса

Реиензенты:

член-корреспондент РАН, доктор исторических наук П. Г. Гайдуков, кандидат исторических наук О. А. Щеглова

Печатается по решению Ученого Совета ИИМК РАН

Земля наша велика и обильна : сборник статей, посвященный 90-летию А. Н. Кирпичникова. - СПб.: Невская Типография, 2019. - 442 с., 170 ил.

Сборник научных статей «Земля наша велика и обильна...», подготовленный к изданию Институтом истории материальной культуры Российской Академии наук, посвящен 90-летию доктора исторических наук, профессора, заслуженного работника культуры РФ Анатолия Николаевича Кирпичникова. В сборнике представлены статьи, написанные историками и археологами из Вюрцбурга, Москвы, Парижа, Перми, Пскова, Риги, Санкт-Петербурга, Старой Ладоги и Сургута. В большинстве работ впервые вводятся в научный оборот результаты новейших открытий в изучении средневековой археологии и истории европейских стран. Статьи иллюстрированы фотографиями, чертежами, рисунками и картами.

Сборник адресован историкам, археологам, филологам, а также широкому кругу читателей, интересующихся историческим прошлым России и сопредельных стран.

ISBN 978-5-907053-29-8

DOI 10.31600/978-5-907053-29-8

(ㄱ Институт истории материальной культуры РАН, 2019

() Авторы статей, 2019

(c) Белецкий С. В., научное редактирование, 2019

() ООО «Невская Типография», 2019 


\section{Содержание}

B. А. Лапшин. Анатолий Николаевич Кирпичников. К 90-летию со дня рождения................. 5

Л. А. Губчевская. «Заповедный» - значит «особо хранимый» .................................................... 8

Л. М. Всевиов (составитель). Библиография работ А. Н. Кирпичникова..................................... 11

A. А. Александров. «Князя поищем, иже бы владел нами и рядил ны по праву»

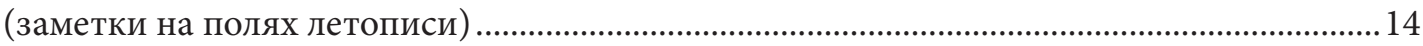

С. В. Белецикий. Геральдические подвески X-XI вв........................................................................30

P. Брузис. Бутафории оружия ближнего боя XIV-XVI вв. на территории Латвии .................50

Ю. А. Виноградов. О терракотовых статуэтках с изображением воинов из Ольвии .............61

К. В. Горлов, Н. В. Григорьева. Фракция новгородского рубля

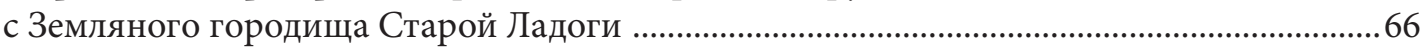

Г. С. Гофман, Т. Ю. Закурина. Изборская крепость в первой трети XIV в. ……………….......70

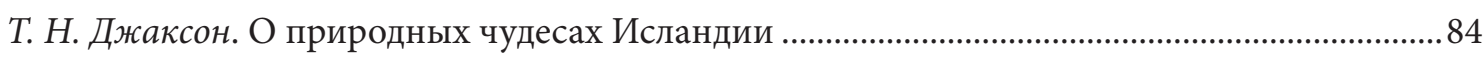

А. Н. Егорьков, А. В. Плохов. Химический состав раннесредневековых стеклянных изделий Рюрикова городища ...................................................................................91

И. И. Еремеев. Фрагмент предмета церковной утвари с Бронницкого городища под Новгородом

M. М. Казанский. О двух традициях декора клинкового оружия эпохи Великого переселения народов на юге Восточной Европы

С. Ю. Каинов. «Большой» меч из Чёрной могилы (предварительные итоги нового этапа изучения)

О. В. Кардащ, 3. Г. Гайдакова. Топоры-секиры у населения Крайнего Севера в XII-XIV вв.: бытовые и ритуальные аспекты

А. А. Кищук, О. В. Овсянников. Из истории поморского летописания конца XVII - начала XVIII в.: «летопись» и рисунки Ивана Погорельского

Л. С. Клейн. Спор о варягах как пережитое.

Н. Б. Крыласова. Комплекс вооружения финно-угорского Рождественского могильника в Пермском крае

Ю. А. Кулешов. Позднесредневековый шлем из собрания Козьмодемьянского культурно-исторического музейного комплекса (к вопросу о традициях и технологиях оружейного производства Генуэзской Газарии) 
А. В. Курбатов. Кожаные детали вооружения и амуниции в древности и средневековье по письменным и археологическим данным .............................................224

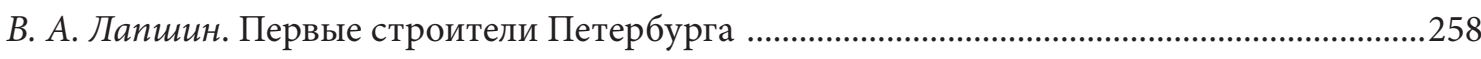

П. А. Миляев. Предметы вооружения XVI-XVII вв. из раскопок на территории ладожского посада

К. А. Михайлов, А. А. Пескова. Находки защитного вооружения из раскопок древнерусского Шепетовского городища (заметки к трудам А.Н. Кирпичникова)

E. P. Михайлова. Двушипные наконечники копий из Которского погоста .............................298

А. Г. Панкратов. Новые данные о пластинчатых панцирях на Руси .........................................312

В. Я. Петрухин. Вещий Олег и «могила в Ладоге» ………….....................................................322

Н. И. Платонова. Г. Косинна и А. А. Спицын: единство противоположностей (к вопросу о «национализме в археологии»)

А. И. Сакса. «Выборгский гром» 1495 г. - легенда или действительность?

Иван III и «Балтийский вопрос» конца XV в.

E. В. Салмина, С. А. Салмин. В поисках захаба: археологические раскопки в Псковском кремле в 2016 г.

Т. Б. Сениченкова, Н. В. Семёнова, О. К. Дмитриева.

Новая находка из старых раскопок

В. Ю. Соболев. Оружие и снаряжение коня из раскопок

Никольского Которского погоста Новгородской земли

П. Е. Сорокин, П. А. Васин. Романские мечи из Приневья и юго-западного Приладожья

P. Спиргис. Ливские подражания готландским брактеатам X-XIII вв.

C. В. Томсинский. Каменные иконки из раскопок древнерусского «Изяславля»

С. Н. Травкин. Повторное использование монет и хронология кладов на территории Юго-Восточной Европы в средние века

Сокращения 
Н. Б. Крыласова

(Пермь)

\section{Комплекс вооружения финно-угорского РожАественского могииьника в Пермском крае ${ }^{1}$}

$\mathrm{H}^{2}$

а территории Пермского края крупнейшим средневековым памятником яв-

ляется Рождественское городище, упомянутое в письменных источниках как городок Афкула (Белавин, Крыласова 2008). Здесь находилась торгово-ремесленная фактория волжских булгар, население было полиэтничным и поликонфессиональным. Городище сопровождается двумя некрополями - мусульманским и языческим.

На языческом могильнике X-XI вв. к настоящему времени вскрыто 1767 м², изучено 339 погребений - количество, вполне достаточное для проведения предварительного анализа состава и распространения оружия в погребальных комплексах. Подобное исследование проводилось А. Н. Кирпичниковым по материалам древнерусских погребальных памятников (Кирпичников 1971: 41-54).

Детали вооружения обнаружены в 95 погребениях Рождественского языческого могильника (28\%), то есть примерно каждый 3-4 погребенный (иногда включая и женщин) имел оружие. Набор предметов вооружения, использовавшийся в погребальном обряде, в целом ограничен тремя основными категориями - наконечниками стрел, топорами и наконечниками копий, а иные виды оружия представлены единичными предметами (табл.). При этом в 26 погребениях (7,6 \%, то есть примерно одно из 3-4 погребений с оружием) в составе погребального инвентаря содержалось по две категории оружия (10 погребений - наконечники стрел + топор; 4 - наконечники стрел + наконечник копья; 3 - топор + наконечник копья) и только в двух погребениях (0,5\%) - по три категории (погр. 78 - наконечник стрелы, топор, наконечник копья; погр. 325 - топор, наконечники стрел и сломанная на части сабля). Сочетание предметов вооружения с элементами конского снаряжения (Крыласова 2017) отмечено в восьми погребениях, в то время как отдельные элементы конского снаряжения (удила, стремя, подпружная пряжка) встречены в 52 погребениях. Таким образом, особой взаимосвязи предметов вооружения с конским снаряжением не прослеживается. Напротив, предметы вооружения присутствовали во всех погребениях с наличием своеобразных комплексов хозяйственных и ремесленных орудий, которые обычно размещались компактным скоплением в ногах погребенного или у изголовья могильной ямы (Крыласова, Белавин 2015).

\footnotetext{
${ }^{1}$ Статья подготовлена при поддержке Российского фонда фундаментальных исследований (РФФИ), проект №17-46-590780 «Хозяйственно-культурный облик средневекового Предуралья (комплексное исследование)».
} 
Н. Б. Крыласова

Та б л и ц а. Распределение предметов вооружения по погребениям

\begin{tabular}{|c|c|c|c|c|c|c|c|c|c|c|c|c|c|c|c|c|}
\hline \multirow[b]{2}{*}{ 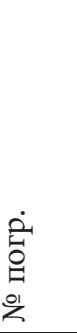 } & \multicolumn{4}{|c|}{ Стрелы } & \multicolumn{6}{|c|}{ Топор } & \multicolumn{4}{|c|}{ Копье } & \multirow{2}{*}{ 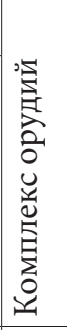 } & \multirow{2}{*}{ 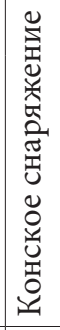 } \\
\hline & 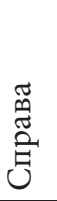 & 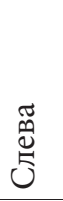 & 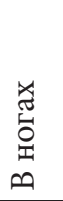 & 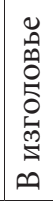 & 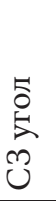 & $\begin{array}{c}5 \\
\stackrel{5}{\vdots} \\
0 \\
0 \\
0\end{array}$ & 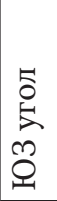 & 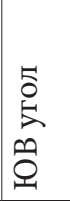 & 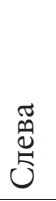 & 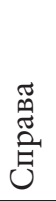 & 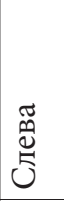 & 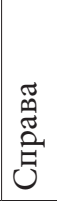 & 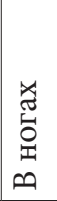 & 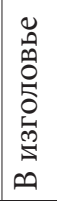 & & \\
\hline 21 & 3 & & & & & & & & & & & & & & & \\
\hline 23 & 2 & & & & & & & & & & & & & & & \\
\hline 36 & & & 1 & & + & & & & & & & & & & & \\
\hline 37 & & & & & & & & + & & & & & & & & \\
\hline 49 & & 2 & & & & & & & & & + & & & & + & \\
\hline 55 & & 2 & & & & & & & & & & & & & & \\
\hline 56 & & & 1 & & & & & & & & & & & & & \\
\hline 59 & & 4 & & & & & & + & & & & & & & + & \\
\hline 61 & & 5 & & & & & & & & & + & & & & + & \\
\hline 63 & & 7 & & & & & & & & & & & & & & \\
\hline 65 & & & 1 & & & & & & & & & & & & + & + \\
\hline 67 & & & 1 & & & & & & & & & & & & & \\
\hline 70 & & & 1 & & & & & & & & & & & & & \\
\hline 73 & & 2 & & & & & & & & & & & & & & \\
\hline 78 & & & 1 & & & & & + & & & + & & & & + & \\
\hline 82 & & 3 & & & & & & & & & & & & & & \\
\hline 88 & & & 1 & & & & & & & & & & & & & \\
\hline 90 & & & 1 & & & & & & & & & & & & & + \\
\hline 93 & & 3 & & & & & & & & & & & & & & \\
\hline 96 & & 2 & & & & & & & & & & & & & & \\
\hline 98 & & 2 & & & & & & & & & & & & & + & \\
\hline 99 & & & 1 & & & & & & & & & & & & + & \\
\hline 102 & & & 1 & & & & & + & & & & & & & & \\
\hline 103 & & 2 & & & & & & & & & & & & & & \\
\hline 108 & & & 2 & & & & & & & & & & & & & \\
\hline 110 & & 3 & & & & & & + & & & & & & & & \\
\hline 111 & & & 1 & & & & & & & & & & & & & \\
\hline 116 & & & 2 & & & & & & & & & & & & & \\
\hline 117 & & & 2 & & & & & + & & & & & & & & \\
\hline 118 & & 3 & & & & & & & & & & & & & & \\
\hline 119 & & & & & & & & + & & & & & & & & \\
\hline 120 & & & 1 & & & & & & & & & & & & + & \\
\hline 121 & & & 1 & & & & & & & & & & & & & + \\
\hline 124 & & 6 & & & & & & & & & & & & & & \\
\hline 125 & & & 1 & & & & & & & & & & & & & \\
\hline 134 & & 2 & & & & & & & & & & & & & & \\
\hline 139 & & 1 & & & & & & & + & & & & & & & \\
\hline 141 & & & 1 & & & + & & & & & & & & & & \\
\hline 149 & 1 & & & & & & & & + & & & & & & & \\
\hline
\end{tabular}


Продолжение таблииь

\begin{tabular}{|c|c|c|c|c|c|c|c|c|c|c|c|c|c|c|c|c|}
\hline \multirow[b]{2}{*}{ 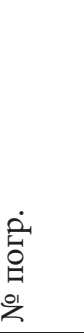 } & \multicolumn{4}{|c|}{ Стрелы } & \multicolumn{6}{|c|}{ Топор } & \multicolumn{4}{|c|}{ Копье } & \multirow{2}{*}{ 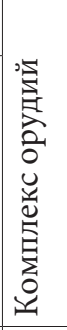 } & \multirow{2}{*}{ 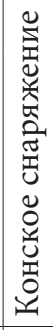 } \\
\hline & 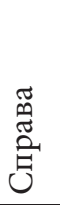 & 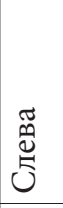 & 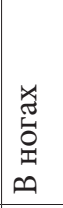 & 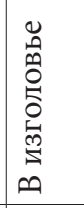 & 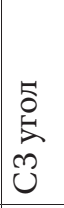 & 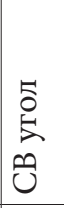 & 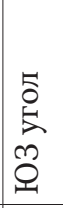 & 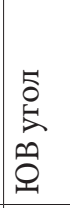 & 芯 & 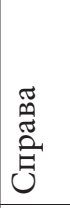 & 总 & 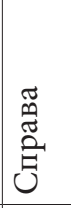 & 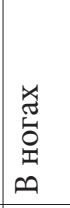 & 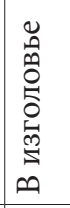 & & \\
\hline 150 & & & 1 & & & & & & & + & & & & & & \\
\hline 152 & 2 & & & & & & & & & & & & & & & \\
\hline 153 & 3 & & & & & & & & & & & & & & & \\
\hline 161 & 3 & & & & & & & & & & & & & & & \\
\hline 169 & & & & & & & & & & & & & + & & & \\
\hline 1796 & & & 1 & & & & & + & & & & & & & + & \\
\hline 180 & & & & & & & & & & + & & & & & & \\
\hline 184 & & 2 & & & & & & & & & & & & & & \\
\hline 185 & & & & & & + & & & & & & & & & & \\
\hline 193 & 2 & & & & & + & & & & & & & & & & \\
\hline 196 & & & & 3 (ж) & & & & & & & & & & & & \\
\hline 197 & & 1 & & & & & & & & & & & & & & \\
\hline 199 & & & 1 & & & & & & & & & & & & & + \\
\hline 203 & & & 1 & & & & & & & & & & & & & \\
\hline 207 & & 3 & & & & & & & & & & & & & & \\
\hline 216 & & & & & & & + & & & & & & & & + & \\
\hline 219 & & 1 & & & & & & & & & & & & & & \\
\hline 221 & & 1 & & & & & & & & & & & & & & \\
\hline 225 & & & & & & & & & & & & & + & & & \\
\hline 227 & & & & & + & & & & & & & & & & & \\
\hline 231 & & & & & & & & + & & & & & & & & \\
\hline 232 & 1 & & & & & & & & & & & + & & & & + \\
\hline 233 & & 5 & & & & & & & & & & & & & & \\
\hline $234 a$ & & & 2 & & & & & + & & & & & & & + & \\
\hline 237 & 2 & & & & & & & & & & & & & & & \\
\hline 239 & & & & & & & & & + & & + & + & & & & \\
\hline 242 & & & & & & & & & & & & & & + & & + \\
\hline 245 & & 1 & & & & & & & & & & & & & & \\
\hline 247 & & 4 & & & & & + & & & & & & & & & \\
\hline 249 & & 2 & & & & & & & & & & & & & + & \\
\hline 250 & & 6 & & & & & & & & & & & & & + & + \\
\hline 251 & & 4 & & & & & & & & & & & & & & \\
\hline 257 & & & 1 & & + & & & & & & & & & & + & \\
\hline 258 & & & & & & & & & & & & & & + & & \\
\hline 259 & 1 & & & & & & & & & & & & & & + & \\
\hline 262 & 2 & & & & & & + & & & & & & & & & \\
\hline 263 & & & 2 & & + & & & & & & & & & & & \\
\hline 2646 & & & 1 & & & & & & & & & & + & & + & \\
\hline 265 & 3 & & & & & & & & & + & & & & & & \\
\hline
\end{tabular}


Окончание таблииь

\begin{tabular}{|c|c|c|c|c|c|c|c|c|c|c|c|c|c|c|c|c|}
\hline \multirow[b]{2}{*}{ 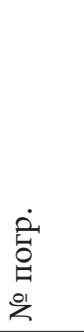 } & \multicolumn{4}{|c|}{ Стрелы } & \multicolumn{6}{|c|}{ Топор } & \multicolumn{4}{|c|}{ Копье } & \multirow{2}{*}{ 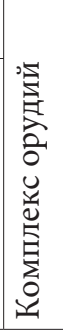 } & \multirow{2}{*}{ 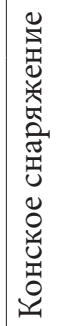 } \\
\hline & 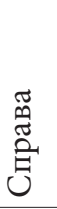 & 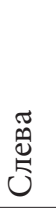 & 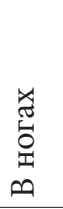 & 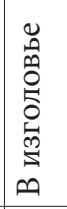 & 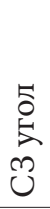 & 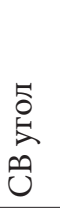 & 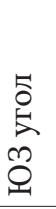 & 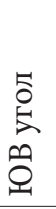 & 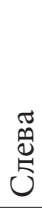 & $\begin{array}{l}\text { 嗎 } \\
\text { 岂 }\end{array}$ & & 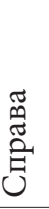 & 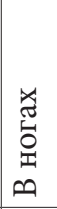 & 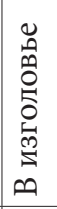 & & \\
\hline 266 & & 1 & & & & & & & & & & & & & & + \\
\hline 270 & & 2 & & & & & & & & & & & & & & + \\
\hline 271 & & & & & & & & & & & & & & + & & \\
\hline 273 & 1 & & & & & & & & & & & & & & & \\
\hline 274 & & 2 & & & & & & & & & & & & & & \\
\hline 279 & & 1 & & & & & & & & & & & & & & \\
\hline 319 & & 3 & & & & & & & & & & & & & & \\
\hline 322 & & & & & & & + & & & & & & & & & \\
\hline 323 & 1 & 1 & & & & & & & & & & & & & & \\
\hline 325 & & & 1 & & & + & & & & & & & & & & \\
\hline 330 & & & & & & & & & & & & & & + & & + \\
\hline 336 & & & & 1 & & & & & + & & & & & & & \\
\hline 341 & & 3 & & & & & & & & & & & & & & \\
\hline 344 & & & & & & & & + & & & & & & & & \\
\hline 347 & 7 & & & & & + & & & & & & & & & & \\
\hline 348 & & 2 & & & & & & & & & & & & & & \\
\hline 354 & & & & & & & & & + & & & + & & & & + \\
\hline
\end{tabular}

Наиболее массовой категорией являются наконечники стрел (181 экз. в 78 погребениях). Они содержались в погребальном инвентаре в количестве от 1 до 7: в 34 погребениях (10\%) - 1 экз., в $23(6,7 \%)-2$ экз., в $12(3,5 \%)-3$ экз. и только в девяти $(2,6 \%)$ - от 4 до 7 экземпляров. В случаях, когда присутствовало более одного наконечника, они, как правило, образовывали компактные скопления, что свидетельствует об их вероятном нахождении в колчане. Наконечники стрел размещались либо справа от погребенного (15 погребений), либо слева (35), как правило остриями к изголовью могильной ямы. В 26 погребениях наконечники (обычно, в количестве 1-2 экз.) располагались в ногах погребенного, и только в двух случаях - в изголовье (причем одно погребение с таким расположением наконечников стрел по составу погребального инвентаря определено как женское).

На рис. 1(1-3) наконечники стрел скомпонованы не по типам, а по комплексам погребений, чтобы можно было наглядно представить состав колчанных наборов X-XI вв. Все наконечники стрел, обнаруженные в погребениях - железные черешковые. Отсутствие костяных наконечников может объясняться очень плохой сохранностью кости на памятнике.

Подавляющее большинство наконечников имеют плоское перо в виде ромба разных пропорций или в виде вытянутой линзы (169 экз. - 93\%). Они подразделяются исследователями на разные типы и варианты (напр.: Белавин, Данич 2006), но для нас важно, что функционально все они предназначались для поражения 

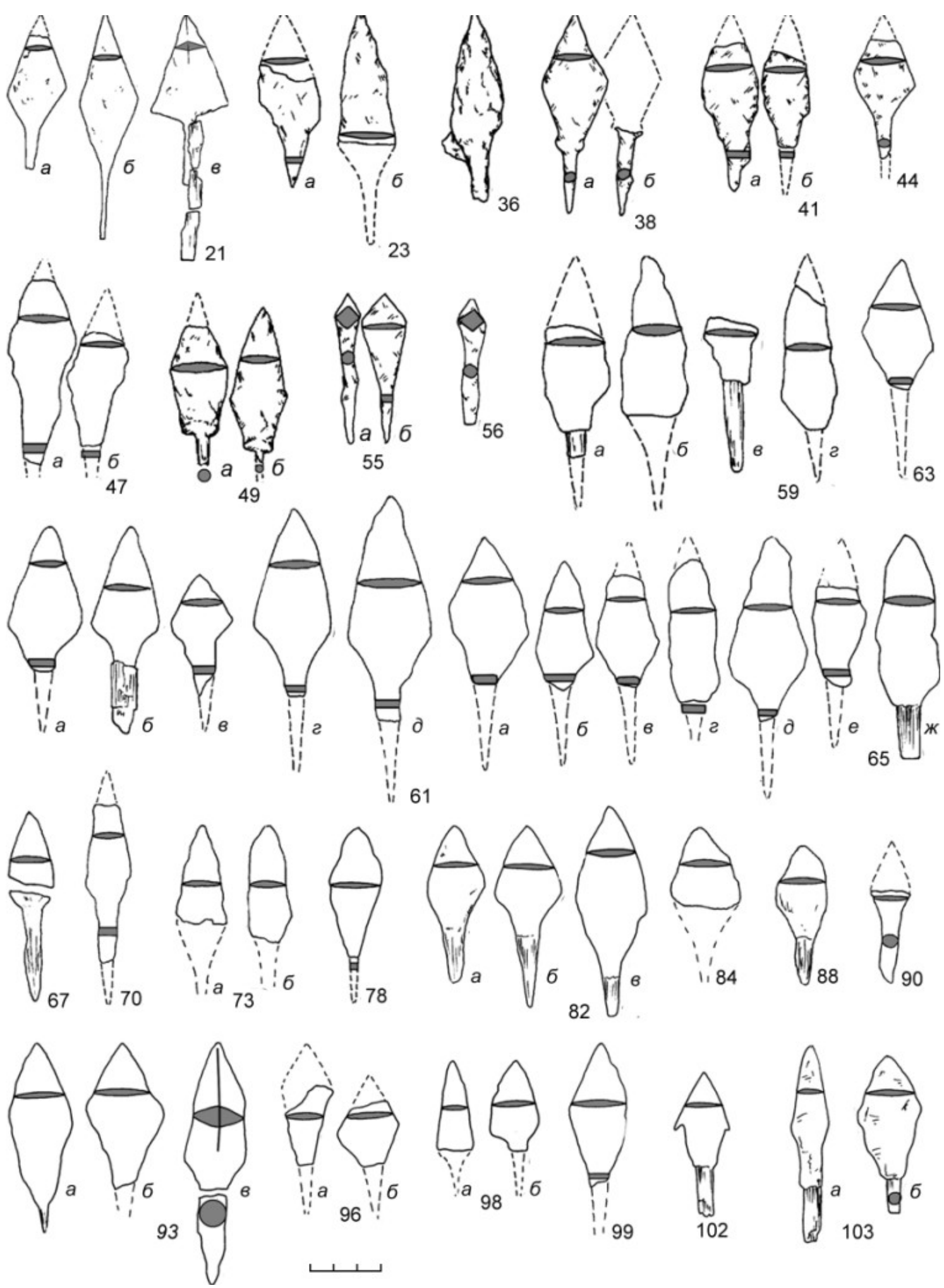

Рис. 1 (1). Наконечники стрел Рождественского могильника (на рис. 1-3 номера соответствуют номерам погребений) 


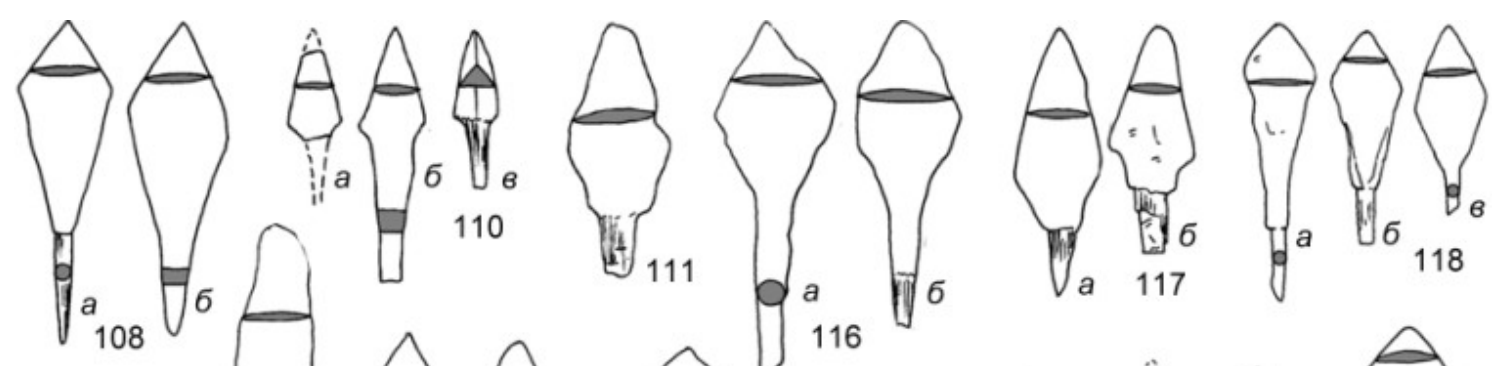

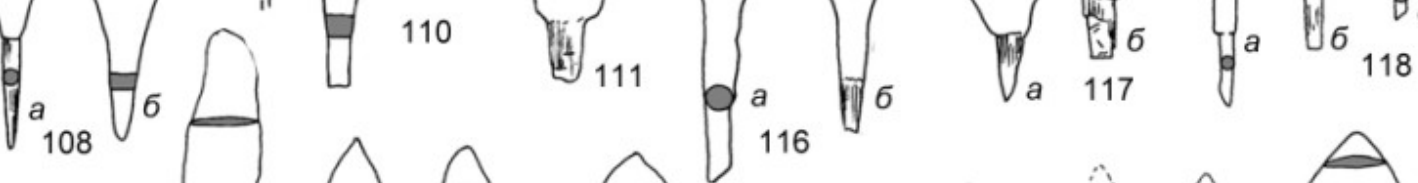
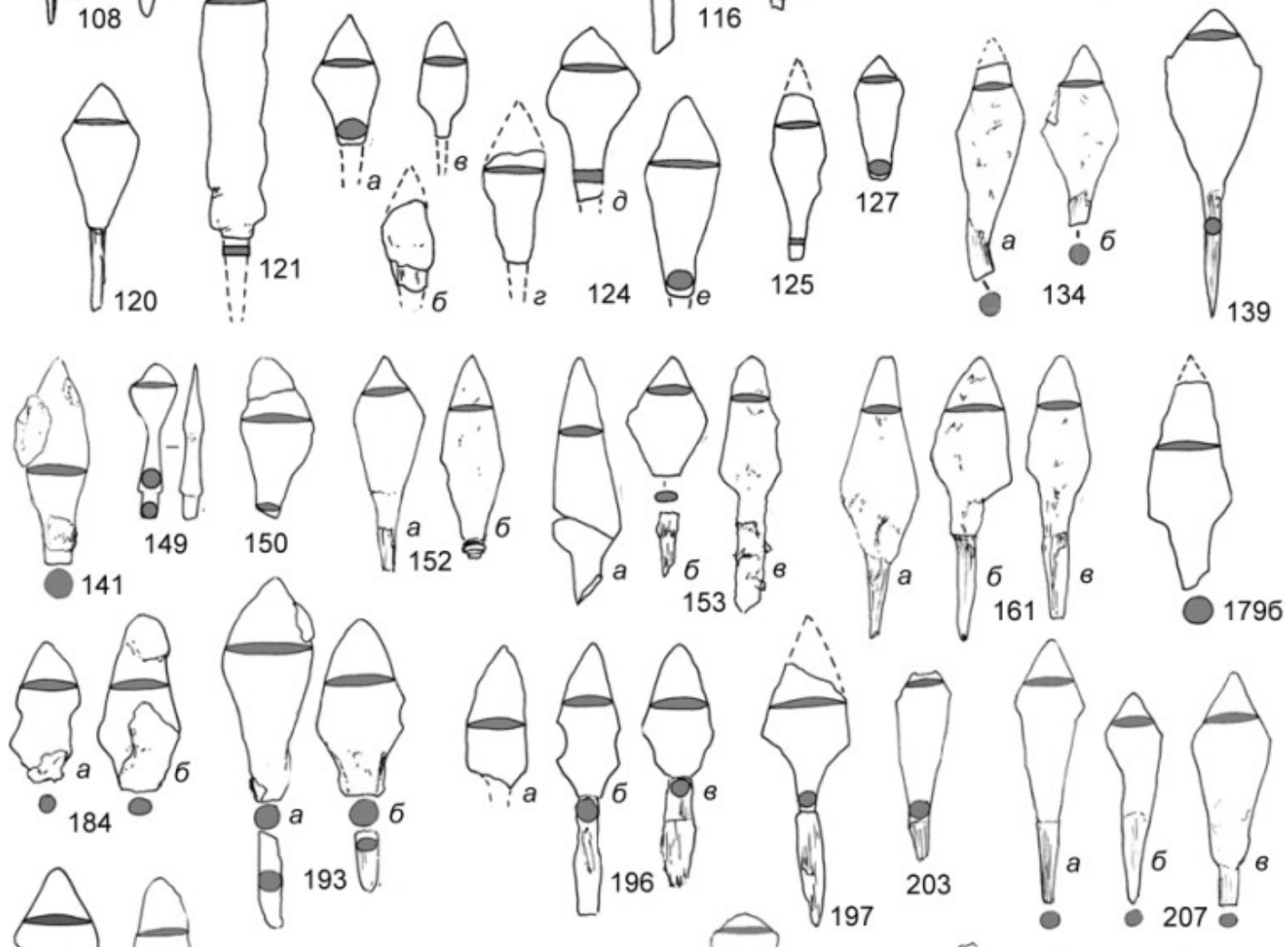
незащищенного панцирем противника или для охоты. Среди наконечников с плоским пером выделяются также два двурогих срезня (погр. 257, 263а) и два треугольных срезня (погр. 233д, 3416) без упора (2\%).

Бронебойные наконечники стрел представлены единичными находками (8 экз. - $4 \%)$. Среди них присутствуют наконечники с массивной боевой головкой ромбовидных очертаний и ромбовидного сечения X-XI вв. (погр. 55a, 56), килевидный сплющенный с прямоугольными плечиками IX-XIV вв. (погр. 93в), треугольный треугольного сечения без упора (погр. 110в), шиловидные ромбического сечения (погр. 319в, 341a), долотовидные (погр. 247в, 263б) (Данич 2011: 100-103). Только в трех погребениях с находками бронебойных наконечников стрел (погр. 110, 247, 263) в составе инвентаря был еще и топор, то есть нет оснований связывать наконечники стрел с вооружением профессиональных воинов.

На втором месте по встречаемости находятся топоры (34 экз.). При почти полном отсутствии клинкового оружия в захоронениях Рождественского могильника ${ }^{2}$ здесь топор являлся своеобразным символом особого социального статуса: топоры нередко находятся в составе богатых погребальных комплексов, в том числе с наличием предметов из драгоценных металлов. Топоры обычно размещались (табл. 1) в одном из углов могильной ямы (в изго-
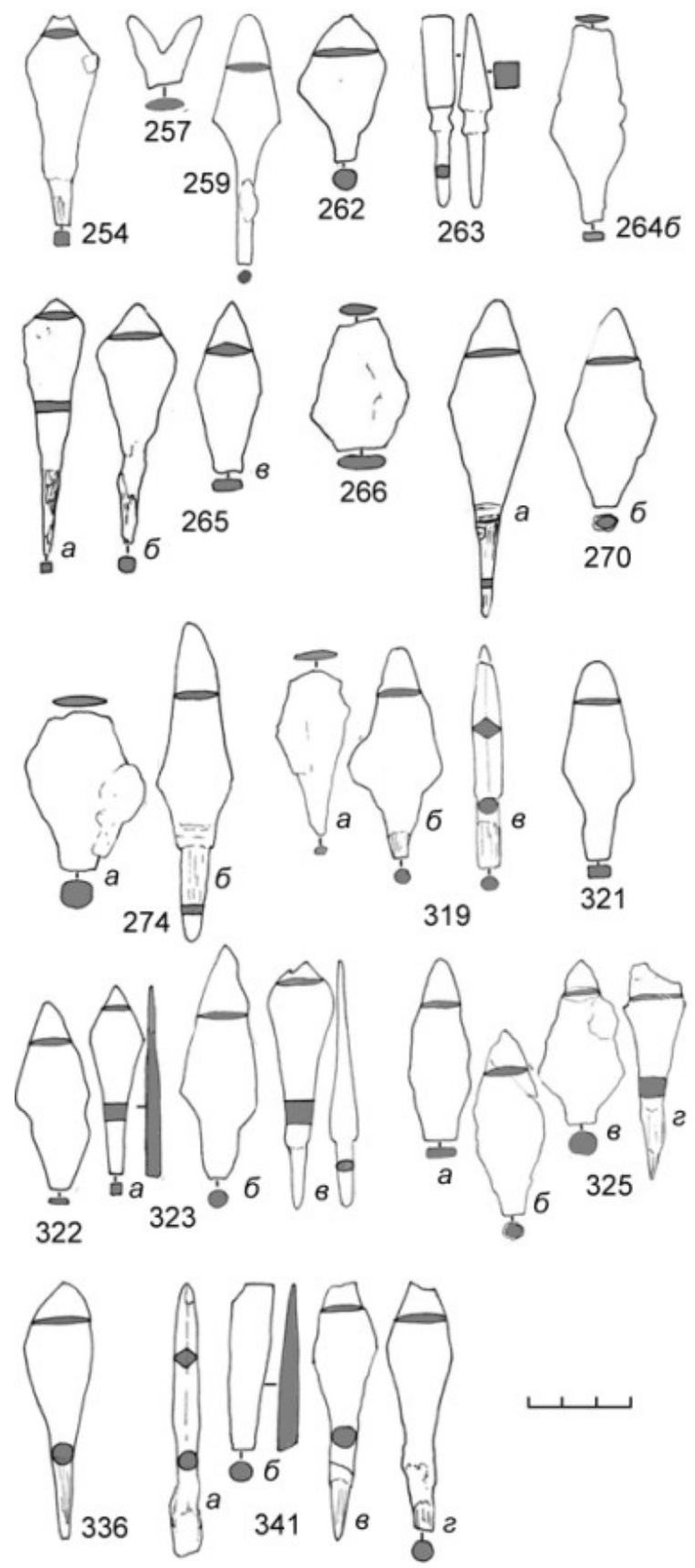

Рис. 1 (3). Наконечники стрел Рождественского могильника ловье в северо-западном углу - 4, в северо-восточном углу - 5; в ногах в юго-западном углу - 4 , в юго-восточном углу 11). Особая система здесь не прослеживается, отмечается лишь преобладание

\footnotetext{
2 По сравнению, к примеру, с Баяновским могильником X в., где в значительной части погребений присутствуют сабли, сопровождающиеся другими видами оружия и элементами конского снаряжения, что может свидетельствовать о наличии профессиональных воинов-дружинников.
} 
расположения в юго-восточном углу в ногах погребенного. Реже топоры помещались в районе пояса погребенного (слева - 5, справа - 4). В некоторых случаях прослеживается, что топор был воткнут лезвием в дно могильной ямы.

Большинство топоров (21 экз. - 61,7\%) принадлежит к типу широколезвийных (бородовидных) топоров с выемкой, опущенным лезвием, преимущественно прямой верхней гранью, с округлым или уплощенным обухом, подтреугольной или овальной втулкой (рис. 2: погр. 78, 102, 110, 117, 119, 139, 141, 149, 150, 193, 216, $227,231,247,257,262,263,322,330,344,347)$. Обычно считается, что такие топоры использовались при обработке древесины как столярно-бондарный инструмент, а топоры меньшего веса могли применяться и как боевые (Данич 2015: 79). Представленные на Рождественском городище топоры имеют вес в пределах 400-600 г и вполне могли использоваться для боевых целей, но, вероятнее всего, являлись универсальными.

Единичными экземплярами среди проушных топоров представлены чеканы с узким треугольным лезвием и молоточковидным обушком квадратного сечения (рис. 2: погр. 1796, 180), чеканы с выемкой, опущенным секировидным лезвием, округлыми щековицами (рис. 2 : погр. 325,354 ), которые имели в большей степени боевое назначение (Данич 2015: 74-75).

Достаточно распространенными на могильнике (9 экз. - 26,5\%) являются втульчатые топоры-кельты (рис. 2: погр. 36, 37, 59, 120, 134a, 185, 239, 265, 336), которые принято относить к рабочим (Данич 2015: 80), хотя нельзя исключать и возможность их использования в боевых целях.

Реже в составе погребального инвентаря присутствуют наконечники копий (11 экз.) и втоки (5 экз.), которые происходят из 14 погребений, при этом только дважды (погр. 234а и 239) отмечено сочетание наконечника копья и втока. Наконечники копий чаще всего размещались слева (погр. 49, 61, 78) или справа (погр. 232, 254) от погребенного, обычно острием к ногам, а также в изголовье (погр. 242, 271, 330) или в ногах (погр. 2646). Втоки размещались в ногах (погр. 169, 225) или в изголовье (погр. 358). В погребении 234а фрагмент втока обнаружен в составе жертвенного комплекса, содержавшего ремесленные инструменты, который находился у северо-восточного угла могильной ямы, а наконечник копья - в ногах, в составе комплекса хозяйственных орудий, характерного для целого ряда мужских погребений Рождественского могильника, и в целом для ломоватовской культуры (Крыласова, Белавин 2015). Наиболее показательным является расположение наконечника копья и втока в погребении 239 - наконечник копья был уложен справа от погребенного острием к ногам, а вток - слева острием к изголовью; таким образом, можно предположить, что слишком длинное для помещения в могилу древко копья переламывалось, и его части укладывались вдоль боковых стенок могильной ямы.

Среди наконечников копий большинство (7 экз.) составляют двушипные (рис. 3: погр. 49, 61, 78, 239, 2646, 272, 354) с втулкой длиной от 10 до 28 см, диаметром $2-3,5$ см. Многие исследователи, в том числе А. Н. Кирпичников, считают, что такие наконечники являются в основном охотничьим оружием (Кирпичников 1966: 18). Но существует и другая точка зрения, согласно которой копья с двушипными наконечниками могли служить и для военных целей (Измайлов 1997: 73; Данич 2010: 25). Два наконечника с ромбическим уплощенным пером, более миниатюрных по сравнению с двушипными, имели втулку длиной 4-9,5 см диаметром 1,5 см (рис. 3:

$$
\approx 208 \approx
$$



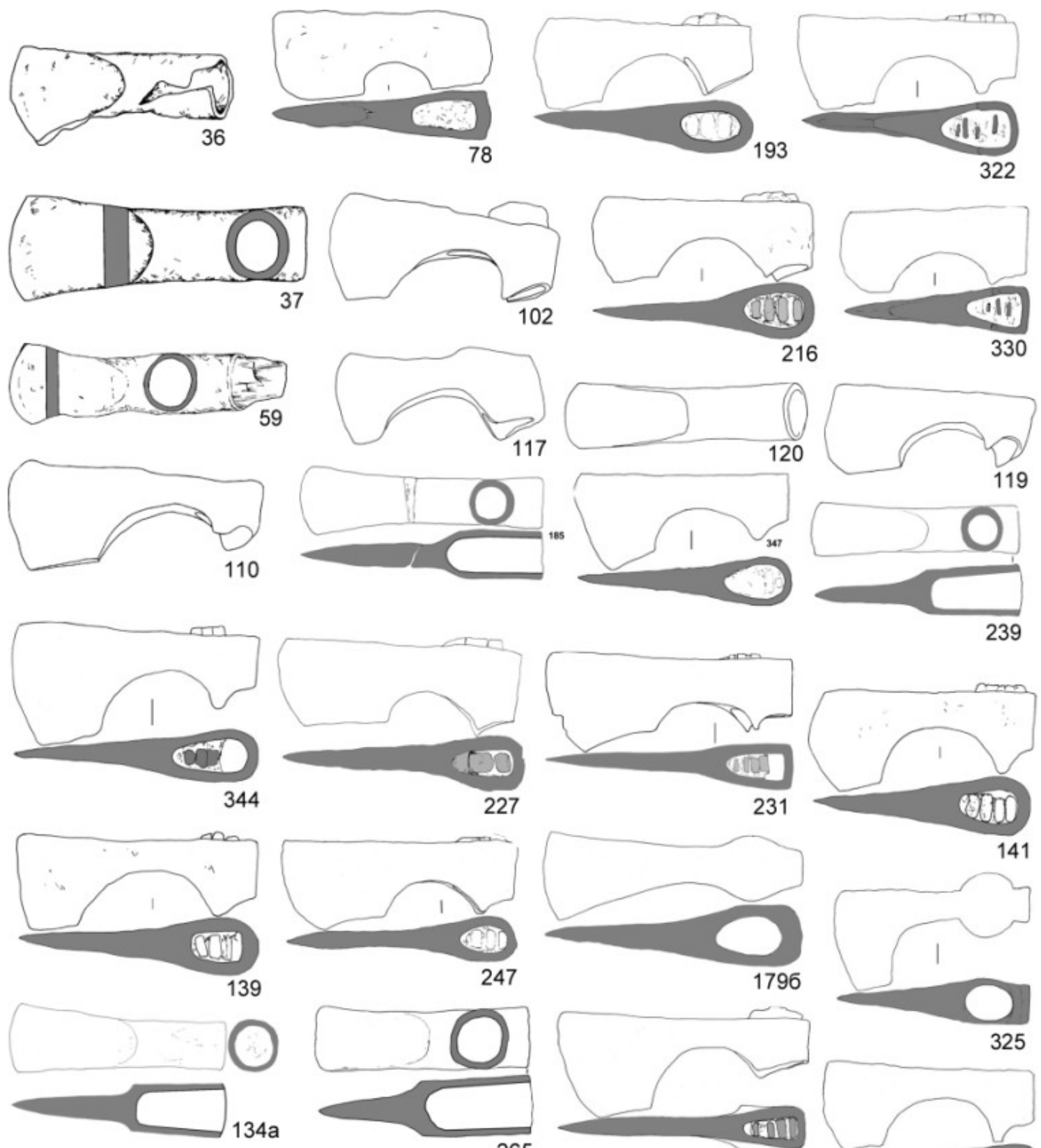

239
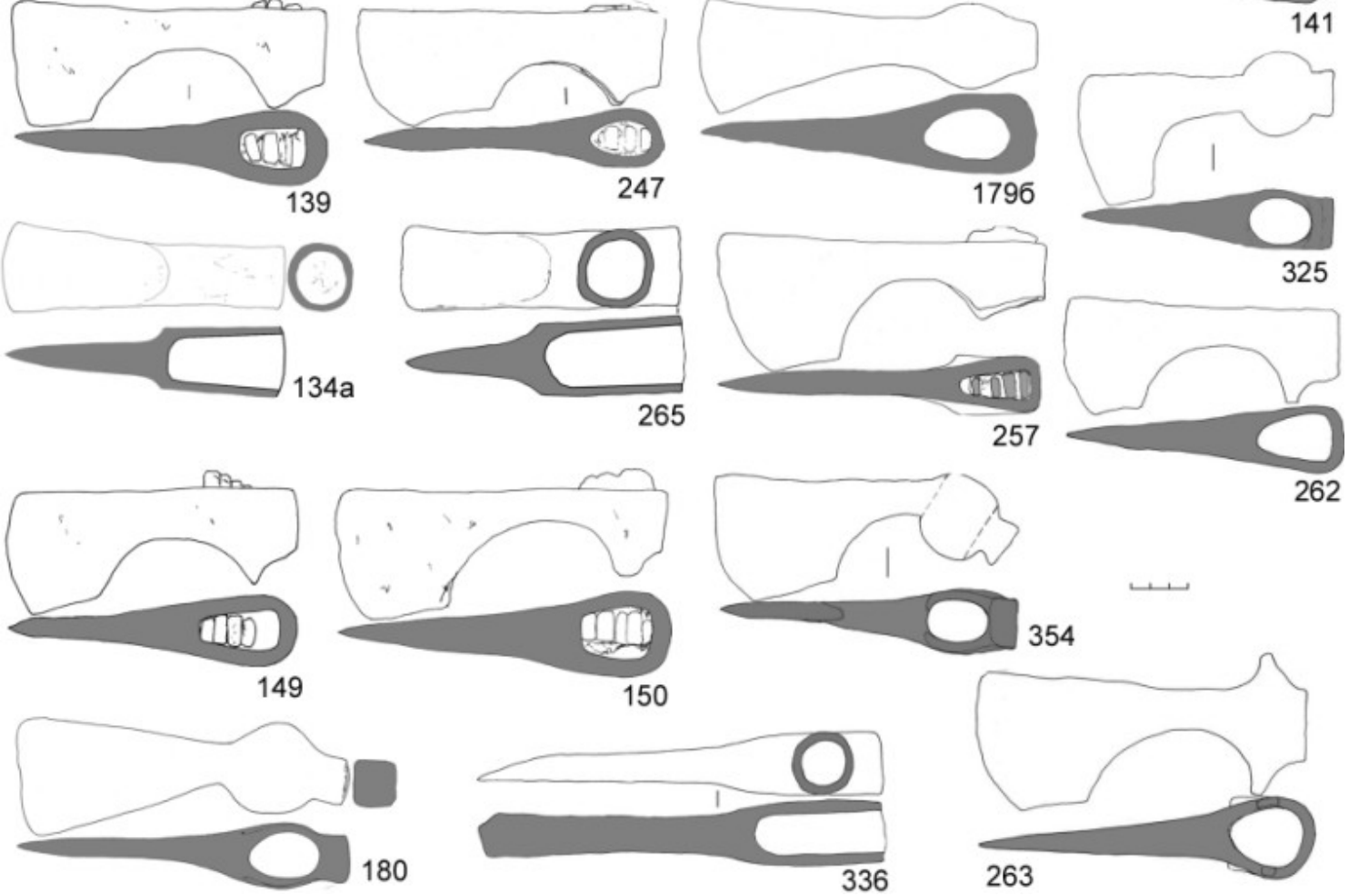

Рис. 2. Топоры Рождественского могильника 


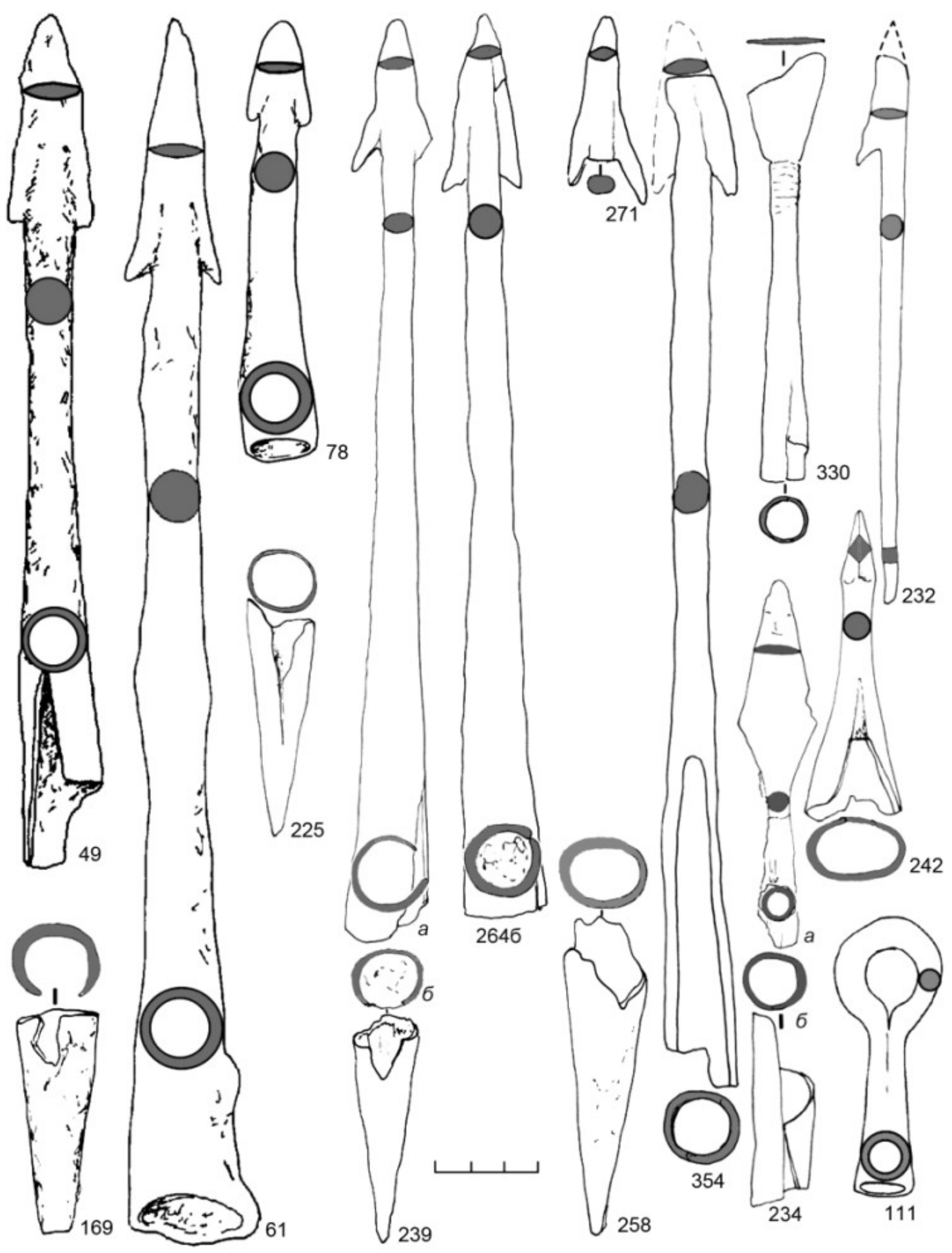

Рис. 3. Наконечники копий, втоки, деталь кистеня из Рождественского могильника 
погр. 234a, 330); эти наконечники, очевидно, предназначались для легких дротиков (сулиц) - метательных копий. В составе древнерусских сулиц А. Н. Кирпичниковым выделены и ромбовидные, аналогичные наконечникам, найденным на Рождественском могильнике (Кирпичников 1966: табл. Х, 7-8). Особо выделяется сравнительно небольшой наконечник с граненой головкой ромбического сечения и мощной втулкой длиной 7 см и диаметром 4,7 cм (рис. 3: погр. 242). Судя по форме головки, он предназначался для пробивания доспехов противника, а большой диаметр втулки свидетельствует о наличии мощного толстого древка, способного выдержать значительное напряжение. Единственный черешковый наконечник с одношипным пером является наконечником гарпуна (рис. 3: погр. 232), которым могли бить рыбу вручную или метать как дротик.

Кроме указанных видов вооружения в единственном экземпляре найдена железная втулка длиной 5 см диаметром 1,8 см с петлей на конце диаметром 3,2 см (рис. 3: погр. 111). Предположительно, она могла являться деталью кистеня. А. Н. Кирпичников отмечает, что гири кистеней привязывались ремнем, веревкой (реже цепью) к короткой палке или просто к руке, но приводит также описание найденной при раскопках Донецкого городища железной конической втулки с петлей на конце, служившей, по-видимому, для прикрепления подвешенной на ремне гири к деревянной рукояти (Кирпичников 1966: 58). Судя по описанию, втулка с петлей, обнаруженная на Рождественском могильнике, полностью аналогична этой находке.

Пока в единственном экземпляре (погр. 325) обнаружена сабля. Погребение, из которого она происходит, по ряду признаков было определено как кенотаф. В центре его располагался сверток, перетянутый ремнем с серебряными накладками. Внутри свертка находились четыре обломка клинка сабли с долом (рис. 4), три наконечника стрел, нож, серебряная рукоять плетки, а также завернутые в согнутую серебряную погребальную маску затыльник деревянной рукояти сабли, обтянутый серебряной пластиной с серебряным орнаментированным грушевидным навершием, разрубленная пополам серебряная трапециевидная подвеска и крупная бронзовая поясная пряжка с изображением медведя в ритуальной позе. Предметы вооружения, находившиеся в свертке, не включены в таблицу, поскольку занимали нетипичное положение, в отличие от топорика-чекана, расположенного в изголовье, и наконечника стрелы

Рис. 4. Сабля из п. 325 Рождественского могильника

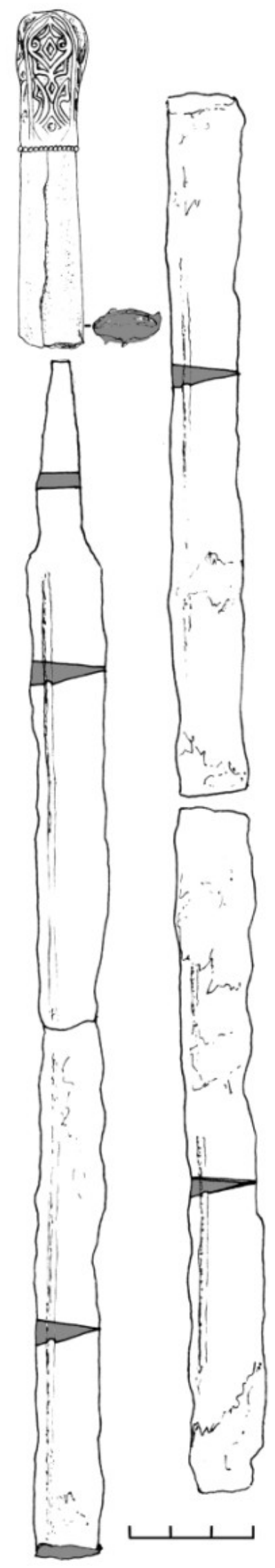




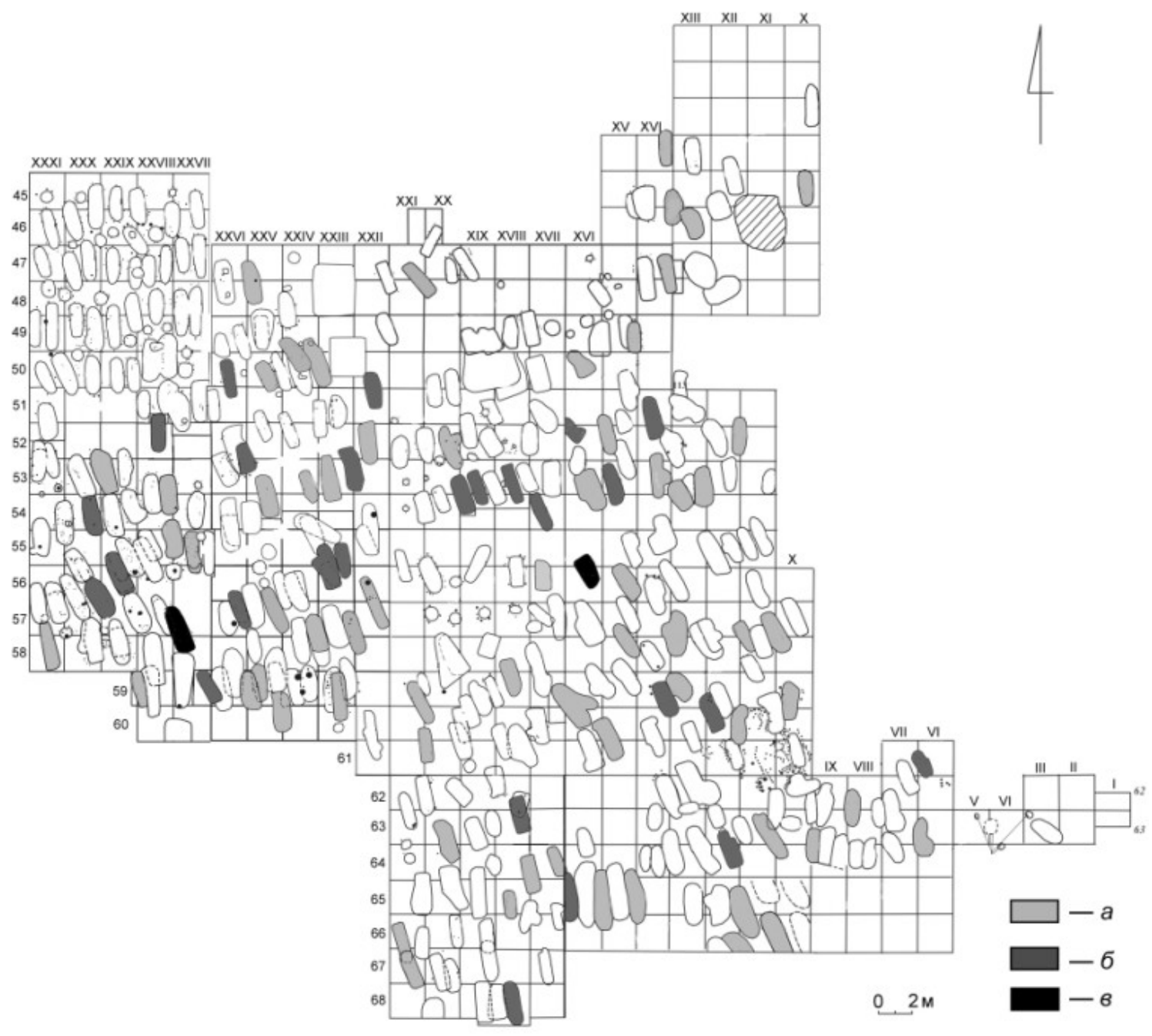

Рис. 5. План расположения погребений с оружием на изученной части Рождественского могильника: $a-$ погребения с одной категорией вооружения; $6-$ погребения с двумя категориями вооружения; в - погребения с тремя категориями вооружения

в ногах погребения. Предположительно, данное погребение, представлявшее собой символическое захоронение первой половины XI в., содержало предметы, принадлежавшие мужчине-воину, представителю социальной элиты - дружиннику или даже вождю (Крыласова и др. 2017).

Интересную информацию дает анализ планиграфического распространения погребений с деталями вооружения на площадке могильника (рис. 5). По имеющимся данным сформировалось представления о том, что ряды погребений, вытянутые вдоль течения р. Обва, содержали семейные захоронения. Погребения с одним видом вооружения (рис. 5,1$)$ распределяются примерно равномерно по всем рядам (за исключением северо-западного участка могильника, где концентрировались бедные захоронения). Погребения с двумя (рис. 5,2 ) и тремя (рис. 5, 3) видами оружия концентрируются в одном ряду примерно в центре изученной части памятника, где прослеживались и наиболее «богатые» комплексы с наличием изделий из драгоценных металлов. Но в остальном погребения, где присутствует более одного 
вида оружия, образуют группы, вытянутые перпендикулярно рядам. Подобная ситуация прослеживалась и с погребениями, содержавшими комплексы хозяйственных и ремесленных инструментов (Крыласова, Белавин 2015), и с погребениями, содержавшими «комплекс коня» (Крыласова 2017). Создается впечатление, что на могильнике были выделены определенные зоны для захоронения людей разного социального и общественного статуса. Возможно, именно этим объясняется тот факт, что при наличии следов наземных сооружений нередко прослеживается взаимоперекрытие погребений; отдельные погребения буквально «втискивались» между совершенными ранее захоронениями, в то время как в этих же рядах имелись свободные пространства - это, вероятно, было необходимо для того, чтобы погребенный оказался в той «зоне» могильника, которая соответствовала его общественному статусу (Крыласова 2017: 48).

В целом проведенный анализ показывает, что, с одной стороны, по составу предметов вооружения рассматриваемый могильник (и, соответственно, территория, на которой он расположен), может быть сравним с выделенной А. Н. Кирпичниковым зоной русско-чудских областей, где отмечается соседство могил с копьями и стрелами при значительном преобладании комплексов с боевыми топорами (Кирпичников 1971: 44). С другой стороны, чисто «военных» комплексов, за исключением комплекса из п. 325, на могильнике выделить нельзя. Обнаруженные предметы вооружения преимущественно имели универсальное назначение, и в одинаковой степени могли использоваться для хозяйственных и военных целей. Это может объясняться, отчасти, тем, что Рождественское городище располагалось в глубине территории на р. Обва, возле устья которой при впадении в р. Кама известно несколько городищ, которые могли обеспечивать оборону. Само городище было достаточно защищено, кроме того, сопровождалось малым городищем - цитаделью (Филипповское). Функционирование городища как торгово-ремесленной фактории булгар определяло род деятельности основной части населения, среди которого преобладали ремесленники, охотники-промысловики, люди, занимавшиеся обеспечением населения продуктами питания, торговцы. Как отмечает А. Н. Кирпичников, «нельзя исключить того, что некоторые погребения с копьями, топорами и стрелами, частями конской сбруи связаны не только с воинами, но и с купцами, ремесленниками, охотниками, пахарями и другими невоенными людьми» (Кирпичников 1971: 42). Однако, учитывая своеобразную зонированность Рождественского могильника, нельзя исключать, что в какой-то его части обнаружится группа погребений профессиональных воинов. В пользу этого предположения может свидетельствовать выявленное погребение, сопровождавшееся клинковым оружием.

\section{Литература}

Белавин, Данич 2006 - Белавин А. М., Данич А. В. Костяные и железные наконечники стрел Рождественского археологического комплекса // Вестник Музея археологии и этнографии Пермского Предуралья. 2006. Вып. І. С. 25-36.

Белавин, Крыласова 2008 - Белавин А. М., Крыласова Н. Б. Древняя Афкула: археологический комплекс у с. Рождественск. Пермь: Пермский филиал Института истории и археологии Уральского отделения РАН, 2008. 603 с. 
Данич 2010 - Данич А. В. Наконечники копий на территории Пермского Предуралья // Вестник Музея археологии и этнографии Пермского Предуралья. 2010. Вып. 3. C. 20-43.

Данич 2011 - ДаничА. В. Типология бронебойных наконечников стрел Пермского Предуралья // Труды Камской археолого-этнографической экспедиции. Вып. VII. Пермь: ПГГПУ, 2011. С. 98-115.

Данич 2015 - ДаничА. В. Классификация средневековых топоров Пермского Предуралья // Труды Камской археолого-этнографической экспедиции. Вып. Х. Пермь: ПГГПУ, 2015. С. 71-124.

Измайлов 1997 - Измайлов И. Л. Вооружение и военное дело населения Волжской Булгарии X - начала XIII в. Казань; Магадан: Северо-восточный НЦ Дальневосточного отделения РАН, 1997. 212 с.

Кирпичников 1966 - Кирпичников А. Н. Древнерусское оружие. Вып. II: Копья, сулицы, боевые топоры, булавы, кистени. Л.: Наука, 1966. 89 с. (САИ. Вып. Е1-36).

Кирпичников 1971 - Кирпичников А. Н. Древнерусское оружие. Вып. III: Доспех, комплекс боевых средств IX-XIII вв. Л.: Наука, 1971. 147 с. (САИ. Вып. Е1-36).

Крыласова 2017 - Крыласова Н. Б. Конь и элементы конской сбруи в погребальном обряде Рождественского могильника в Пермском крае // Труды Камской археологоэтнографической экспедиции. Вып. XIII. Пермь: ПГГПУ, 2017. С. 45-55.

Крыласова, Белавин 2015 - Крыласова Н. Б., Белавин А. М. Комплексы орудий в мужских захоронениях ломоватовской культуры как отражение основных хозяйственных и производственных занятий населения // Magistra Vitae: электронный журнал по историческим наукам и археологии. 2015. № 6 (361). С. 16-27.

Крыласова и др. 2017 - Крыласова Н. Б., Белавин А. М., Подосенова Ю. А. Новый «венгерский комплекс» из раскопок Рождественского могильника // Вестник Пермского научного центра. 2017. № 4. С. 91-99. 